Meta

Journal des traducteurs

Translators' Journal

\title{
Cohesion and the Teaching of Translation
}

\section{Barbara Folkart}

Volume 33, numéro 2, juin 1988

L'enseignement de la traduction au Canada - Teaching Translation

in Canada

URI : https://id.erudit.org/iderudit/002755ar

DOI : https://doi.org/10.7202/002755ar

Aller au sommaire du numéro

Éditeur(s)

Les Presses de l'Université de Montréal

ISSN

0026-0452 (imprimé)

1492-1421 (numérique)

Découvrir la revue

Citer cet article

Folkart, B. (1988). Cohesion and the Teaching of Translation. Meta, 33(2),

142-155. https://doi.org/10.7202/002755ar d'utilisation que vous pouvez consulter en ligne.

https://apropos.erudit.org/fr/usagers/politique-dutilisation/ 


\title{
COHESION AND THE TEACHING OF TRANSLATION
}

\author{
BARBARA FOLKART \\ University of Ottawa, Ottawa, Ontario
}

1.

\section{AN EXTENDED DEFINITION OF COHESION}

In this article I shall not be limiting cohesion, as seems generally to be done, to intersentential linkings such as those achieved through anaphora, repetition, parallelism, lexical sets and the like. Rather, I shall be defining cohesion semiotically, as the integration, on both the expression - and content - planes, of substance, or formants, into an overarching form, at whatever rank this integration may occur. Thus, on the expression plane, distinctive features are grouped into bundles to form phonemes, which are then integrated into morphemes that in turn form syntagmata, and so on up through the rank of the entire text, with any given rank constituting the substance of the following one and the form of its predecessor. Similarly, the content plane, while non-isomorphic to the expression plane, is characterized by the integration of semantic markers into bundles that are ultimately actualized as lexical items, and of these lexical items into more extended units of content that undergo successive integrations until the "message" of an entire text is produced. Such integration is of course rule-governed and nonrandom, following well-defined laws that provide criteria of well-formedness at every rank. As Roland Barthes put it long ago :

$+\frac{5}{2}$

La forme, c'est ce qui peut être décrit exhaustivement, simplement et avec cohérence ... par la linguistique, sans recourir à aucune prémisse extra-linguistique... ${ }^{1}$

Reror

The integration of substance into form occurs both syntagmatically and paradigmatically. The notion of paradigmatic form is especially useful in dealing with stylistic, registral and rhetorical phenomena, which may be defined, not as deviations with respect to a forever elusive norm, but merely in opposition to the set of all other items (cosubstance, so to speak) that could have filled the same slot or, alternatively, according to the relative degree of formalization which they represent. From this standpoint, the relatively marked term - whether it be lexical, syntactic or rhetorical - is one which represents a higher degree of formalization than the relatively unmarked one. In the following tree, derived from entries in Hayakawa's Dictionary of Synonyms and Related Words, the polivalent item good is selected, in the Hjelmslevian sense, by the increasingly "oligovalent" items to the right of it, which correspond to successively higher degrees of semantic formalization and accept a far more limited range of collocates :

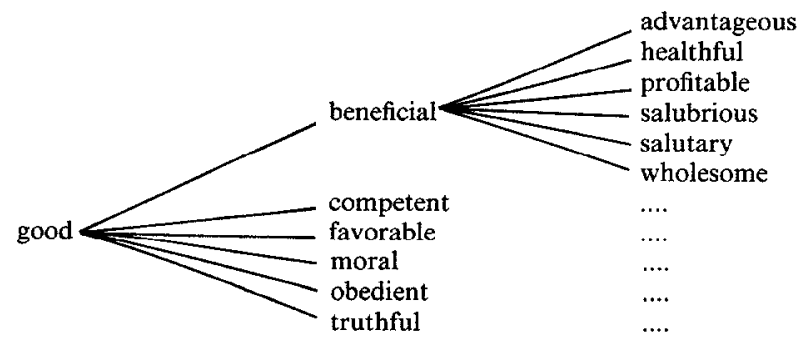


Stylistically marked syntactic items also result from a higher degree of elaboration, necessitating more transformational manipulations (embeddings, frontings, etc.) than simple, straightforward constructions. Similarly, rhetorically marked items represent a higher degree of formalization than the unmarked items that might have filled the same slot ; figures such as metaphors and intertextual allusions bring into play not only the segment actualized at the surface of the text, but a virtual, rhetorically unmarked segment with which they form an equivalency class :

... past rows of squat bungalows, every garden drooping, past grenadiers [vs tall, narrow houses] of red brick, lace curtained, past ancient cement-faced cottages with sagging roofs...

... smiling now like a girl caught in fragrant delight [vs flagrant delit]

This extended definition of cohesion subsumes the conventional one, which is merely a special case of the integration of substance into form. Suprasentential linkings such as repetition and parallelism (" isotaxies", to use Rastier's term), result when a recognizable pattern, or form, is acturalized racurrently by substance occurring at different points of the text. Thematic, lexical or conceptual linkings are "isosemíes" resulting from the projection of a semantic equivalency class onto the combinatory ehain. Anaphora relaying a common antecedent are substance integrated into form through their co-reference.

Since neither form nor formants are absolutes, cohesion and cohesive devices, thus defined, are observable at every conceivable rank, from the phoneme to the text and beyond, through the work of an author, to the genres embodied by specific texts and finally to the polysystem as a whole. Clearly, some of these ranks (the phemic, the phonemic) are of relatively little interest to the practitioner or the teacher of translation, whereas others may play a more important role in some types of translation than in others.

\section{RELEVANCE FOR THE THEORY AND TEACHING OF TRANSLATION}

From the translation theoretical standpoint, at least, as well as from the standpoint of translation teaching, there are advantages to defining cohesion as the integration of substance into form, regardless of the rank or the axis involved in such integration.

$+7$

\subsection{THE TRANSLATION THEORETICAL STANDPOINT \\ 2.1.1 The "entropisation" of the text}

There is a demonstrable tendency of translation in general to regress from form to substance, with a subsequent loss of ordering and increase of textual entropy (a process I have referred to elsewhere as "entropisation") ${ }^{2}$. Such regressing, while observable at virtually every rank, is particularly flagrant at the sentential and infrasentential levels.

Syntagmatically, this tendency is manifested at the rank of the sentence as complex syntactic structures regress, at the surface of the target text, to the simpler structures underlying them :

A stylish reworking of the uneven though often brilliant 1948

Preston Sturgis film about a

jealous conductor and his stun- 
ning child bride, with an outstanding comic performance by Dudley Moore.
Ce film est une refonte stylisée

[sic] du film réalisé en 1948 par Preston Sturgis qui relatait l'histoire d'un chef d'orchestre jaloux et de sa ravissante jeune épouse et qui bien que souvent brillant comportait de moins bons passages. Par son rôle comique, Dudley Moore donne tout son éclat au film.

At a lower rank, lexical collocates exhibit the same tendency, with marked terms representing a high degree of formalization regressing to polyvalent items :

the precision of his comic timing > son grand talent de comique

Paradigmatically, there is a definite tendency for individual lexical items to regress to distinctly less marked substitutes : the important-sounding time-sensitive mail emblazoned on the enveloppes in which the Nissan corporation sends out coupons to be redeemed prior to a certain date quite naturally runs downhill into courrier urgent, losing all the pretentious, hi-tech connotations which set it several notches above its unmarked referential equivalent, urgent mail. Whereas time-sensitive mail unfailingly evokes urgent mail, thus setting up an equivalency class, courrier urgent evokes nothing at all : the paradigmatic form which in the source-text linked the stylistically marked term in praesentia and the "neutral" item in absentia has collapsed into a single item that could just as well have been derived from the substance urgent mail.

Similar regressions of paradigmatic form to substance occur every time an allusion is lost in the process of translation (robot pensant $>$ thinking robot), a registrally marked item is replaced by a more "neutral" one (châsses > eyes and cache-tronche > scarf in a translation of Boris Vian's "Loup garou") or a stylistically marked construction is mapped over onto a straightforward one.

Of course, creative input by an imaginative translator can reverse this tendency of translation to run downhill, but not necessarily at any specific point. Such reversal is usually an overall phenomenon, and it is when creative input occurs elsewhere in the text that one speaks of compensation.

\subsubsection{Entropisation and interlanguage}

In the examples just given, only stylistic components of meanings are lost : the hitech time-sensitive is replaced by the common garden-variety urgent, but the target-text violates neither the norms nor the usage of the target language. And generally speaking, the entropisation of the text most usually manifests itself as a banalisation : the crisp, incisively-written source-text, blunted by translation, degenerates into something distinctly more flaccid.

Entropisation can go much further, though : in the limiting case, the repression from form to substance can cause the text to degenerate into interlanguage, as in Newmark's eloquent (if possibly inauthentic) example :

sa faible viscosité en solution, son bas poids moléculaire

its feeble viscosity in solution, its low molecular weight

suffisants pour l'empêcher de franchir à l'état normal sufficient to prevent it crossing at the normal state

les parois des capillaires, rénaux en particulier,

the partitions of the capillaries' renal in particular, 
expliquent qu'une de ses grandes fonctions biologiques

explain that one of its great biological functions

soit représentée par son rôle dans le maintien $d u$

is represented by its role in the maintenance of the

volume sanguin

blood volume

The fact that one can so easily, using the crudest possible literal translation techniques, reconstitute a perfectly idiomatic source-text from an interlinguistic passage is of the utmost significance. It demonstrates that interlanguage results quite simply from processing the source text and choosing one's units of translation at too low a rank. Newmark's example is the product of a regressive process that breaks form down into substance ; the juxtaposition of feeble and viscosity, for example, is a vertical mapping of highly compartmentalized segments abstracted from their co-substance, a mapping that takes no account of the combinatory constraints on an item like feeble and makes no attempt to achieve horizontal matching. In the limit, processing is morpheme-bound, and one arrives at the hypothetical example concocted by Catford :

it is rain ing cats and dogs

il est pleu-vant chats et chiens +7

\subsection{THE STANDPOINT OF TRANSLATION TEACHING}

Although interlanguage is merely a limiting case, it is illuminating in that it results from what is arguably a universal phenomenon, the tendency of translators in general and student translators in particular to process texts and choose their units of translation at ranks significantly lower than those at which meaning, be it referential, pragmatic or stylistic ${ }^{3}$, is generated.

\subsubsection{Repressions at sentence- and infrasentential ranks}

At one extreme, the most flagrant translation errors perpetrated by beginning students translating into $\mathbf{L} 2$ occur at the sentential or infrasentential levels. Such students regularly produce texts that are riddled with interlinguistic forms violating both syntagmatic and paradigmatic orderings.

Syntagmatically, faulty lexical collocations abound ${ }^{4}$ :

the employee to whom they confided this week's receipts

- follow a programme

the researchers attacked very general fields

as do deviant grammatical collocations at every rank from the sentence down on through the morpheme :

$\checkmark$ sentence level + NP

A few millions of educated citizens, free with their time, relatively rich, determined to take full advantage of life will they accept for a long time to be isolated?

- VP

$\mathrm{V}+$ Prep. $\mathbf{P}$

At the time of experiment and study succeeds the time of work and leisure These days of leisure resemble to those of refusal $\mathrm{V}+\mathrm{AdV}$

Thousands of years ago, the sharing of masculine and feminine functions has been designed to fulfill pressing necessities 
- NP

The rage of not to die

A large amount of amateur translators

$\rightarrow \mathrm{V}$

$\mathrm{V}+$ modalizer

The considerable amount of knowledge that man has known to accumulate over the centuries

Aux. + Part.

$\mathrm{He}$ is gone to the Bahamas

- morpheme

The early researches in artificial intelligence

Paradigmatically, one notes the high frequency of lexical items chosen with little sensitivity to the structuring of the TL lexical fields, very often as a result of vertical matchings of signifiers (faux amis, or the so-called "formal equivalents" - a term which for obvious reasons I eschew), rather than of horizontal matchings to items integrated into forms :

les chercheurs reviennent à la conception de programmes spécifiques

$\emptyset$ searchers now return to the conception of specific programs

I would claim that, rather than merely attributing such forms to interference between the dominant and second languages (and interference, in the last analysis, is merely the transfer at inappropriately low ranks of internalized $\mathrm{Ll}_{1}$ patterns), it is pedagogically more expedient - at least in a translation as opposed to an ESL course-to attribute them to a tendency of the student to process the source-text and to map it onto the target language at ranks significantly lower than those at which the meaning of the text is generated.

A number of empirical observations would seem to support this view. In the first place, ESL students perform better when writing directly in English than when translating from L1 into English (although this could be attributed to a higher degree of interference from the translation source text in praesentia than from $\mathbf{L l}$ patterns stored but only virtually present in the case of direct writing). In the second place, exercises in sight translation provide a certain amount of "raw" evidence to corroborate the view that processing occurs at too low a rank : even though they have had it drilled into them that it is the collocation verb + adverbial which determines whether the passé composé is to be rendered by a simple past or by a present perfect, second-year Francophones sight-translating into English operate as if by reflex at the level of the morpheme :

J'ai mangé des crevettes hier

*I have eaten $\phi /$ some shrimp yesterday

rather than at the level of the syntagma. Rather predictably, the tendency to fall back on a morpheme- or word-bound approach - as if the span of cognitive and syntactic retention were insufficient - is more pronounced in sight translation into the second than into the dominant language, as is shown by the oral sight translations produced by candidates taking the examination for entrance into the interpretation programme of the University of Ottawa.

Even prepared written translations provide definite evidence of a highly segmented approach characterized by a regression of form to substance. In the following rendering, the singular knowledge derives correctly from the plural connaissances but is 
relayed by the anaphora they, which quite clearly results from a vertical mapping of the substance les rather than of the co-referential form connaissances + les :

acquérir des connaissances dans une spécialité gain knowledge in a specific field,

les gérer et les structurer

manage and structure them

Such over-segmentation would seem to be a fundamental reflex, judging by the following, authentic examples, which are perhaps all the more indicative that they were produced under the pressure of an examination :

on leur fit l'aumône de l'assistance

we make them the charity of the assistance

people give them $\varnothing$ alms of $\varnothing$ charity

Additional evidence to support the view that processing tends to occur at too low a rank is provided by the performance of 4th year Anglophone students translating technical texts into their dominant language. Technical translation into $L 1$ is in some respects a privileged domaine of observation, on the one hand because insufficient mastery of the target language can no longer be invoked as a cause of inadequate performance, on the other hand - and far more significantly from our point of view - because students lacking familiarity with the conceptual content tend reflexively to adopt a language-bound approach as a coping mechanism. Such students consistently produce distortions of what Brian Mossop has termed "the pattern of meaning" (i.e. the form of the content) that are indicative of a word-, clause- or sentence-bound approach :

La bielle travaille à la compression dans les temps de compression, de détente et d'échappement et à la traction au cours de l'admission.

The connecting rod works on compression during the compression, power and exhaust strokes and on traction during the intake stroke.

\subsubsection{Regressions at suprasentential level (discourse)}

There is also, of course, ample evidence that the regression of form to substance occurs at the suprasentential ranks (paragraph, text) as well. Student translations are notorious for the intersentential anacolutha produced when a modification made in the structure of a given sentence is not followed through in the next sentence :

If the connecting rods are not rigid enough, they may buckle. This is why it is always designed with a relatively high safety factor.

Such a sentence-bound approach is prevalent even among more advanced students, who are quite capable of rendering sentences within a paragraph in a way that negates the givens established by the paragraph heading and thus violates the pattern of meaning of the text ("The camshaft is located under the valves, therefore operating them directly", in a section subtitled "the overhead valve engine").

Even students working at the M.A. level may exhibit a tendency to process the source-text at inappropriately low ranks. This is particularly true in literary translation, where semiotic structures are most frequently operative at the rank of the entire text and require an extended processing span.

All my evidence thus seems to indicate a very strong tendency to process at the level of substance rather than of form, the only difference between the novice working into $\mathrm{L} 2$, the fourth-year student working into $\mathrm{L} 1$ and the accomplished translator resid- 
ing in the fact that the greater the proficiency of the translator, the higher the rank at which the regression of form to substance occurs on the average.

To counteract this tendency, which keeps graduating students short of true professionalism and constitutes, together with an insufficient command of $\mathrm{L} 2$, the major impediment to satisfactory performance by beginning students, I propose an overall strategy, many of whose constituants are fairly standard, but which is perhaps novel in its emphasis on stretching the span of syntactic and cognitive processing.

\section{APPLICATIONS TO THE TEACHING OF TRANSLATION}

Two main groups of exercises may be envisaged to wean students away from their instinctively rank-bound approach : exercises in recognizing form and exercises in reconstituting it.

\subsection{EXERCISES IN RECOGNIZING FORM}

These are designed to draw the attention of the student to the patterns of both expression and content that are present at different ranks throughout the text.

\subsubsection{Infrasentential Ranks}

\subsubsection{Lexical items}

Beginning students, particularly those translating into L2, must be alerted to the fact that what Maurice Pergnier has termed the message meaning of any specific item is ultimately determined by the semantic forms that shape entire sentences, paragraphs and texts. This point can be made by giving them passages containing context-sensitive items for which rank-bound equivalents would be totally unsuitable and asking them to determine the message meaning of these items. Thus, in the following passage :

Il y a des millénaires que le partage des fonctions masculines et féminines s'est accompli pour répondre à des nécessités impérieuses. Depuis ces temps reculés, les besoins démographiques du clan sont devenus ceux des nations. Jusqu'à la fin du XIXe siècle, la mortalité et une relative pénurie forçaient toujours les femmes à beaucoup enfanter, et à allaiter longtemps. Leur fonction essentielle restait donc normalement le maternage. Cela ne les empêchait nullement de travailler hors du foyer, mais la société masculine, toujours maîtresse du terrain $d u$ travail social, leur donnait seulement des rôles subalternes.

Aujourd'hui que la surpopulation menace nos pays, nous pouvons nous demander ce qu'il advient d'un statut qui continue de départager les fonctions masculines et féminines selon l'ancien schéma. Qu'en est-il aujourd'hui d'un partage des rôles défini il y a des millénaires pour répondre à des exigences sociales réelles, mais qui ont aujourd'hui disparu?

the immediate rendering partage $>$ sharing is precluded by a pattern of meaning stressing the obsolescence (and unfairness) of a division of labour based on societal forces that have long since disappeared. (Recourse to the form constituted by the cognate pair partage, départager would also be helpful here.) Similarly, social work is ruled out as an equivalent of travail social by the semantic opposition lexicalised through the contrasting series enfanter, allaiter, maternage and travailler hors du foyer (not to mention the anachronism of social work referring to a period overlapping with pre-history).

\subsubsection{Sentence constituants}

Once the message meaning of individual lexemes has been established, one can begin to stress the integration of these items into higher ranks. In the passage just quoted, attention can be drawn to constituants such as le partage [des fonctions] s'est accompli, which functions globally, as a "verbe de discours", with the deverbal partage carrying the 
semantic load and s'est accompli providing the grammatical content ("verbality"). Similarly, once its individual constituants have been clarified, a noun phrase such as la société masculine, toujours maitresse du terrain du travail social must be perceived in terms of its global content : men + control + work outside the home.

It then becomes possible to contrast renderings such as :

Thousands of years ago, gender roles differentiated

or:

a society in which men controlled all work outside the home

with word-bound renderings such as the following, authentic specimens produced by Francophones working into L2 :

Il y a des millénaires que le partage des

Thousands of years ago $\varnothing$ the sharing of

fonctions masculines et féminines s'est accompli

masculine and feminine functions has been accomplished

or

la société masculine, toujours maitresse du terrain du

the male society, still master of the field of

travail social

social work

It is at this stage that emphasis will be placed on the necessity of perceiving lexical and grammatical collocations (le continent noir peut fournir un apport considérable/il y a des millénaires le partage des fonctions s'est accompli) as more than just the sum of their individual constituants (fournir + apport/il y a des millénaires + s'est accompli).

\subsubsection{Sentence Rank}

As earlier examples have shown, a significant number of students translating into L2 have difficulty in rendering sentences other than by a sort of linear, left-to-right processing which totally obscures the hierarchies obtaining between successive levels of form and results in more or less markedly interlinguistic renderings. Sensitizing such students to the importance of grasping overall sentence structure before beginning to translate will not only improve the quality of their work at sentence level but will also provide a basis for understanding the mechanics of discourse-level integration.

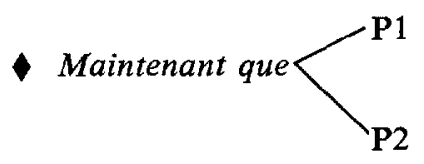

\section{il faut se demander si $\mathrm{P} 3$}

- C'est grâce à la traduction qu'ont pu être communiqués 


\subsubsection{Blocking out Sentence Structures}

A useful technique for overcoming the "obsession with words", or substance, that prevents students from perceiving sentence-level structures, or form, is to "block the sentence out", replacing functional units with symbols such as [S] ujet, $P[$ roposition], $N[o m]$ :

Once these overall structures have been laid bare, considerable emphasis is placed on giving form priority over substance in the re-encoding process : the "trunk" (sentence-level) structures must be taken care of first, "branches" (clause-level structures) must be filled in before "twigs" (lower-level structures on down through individual lexical items) :

Plusieurs millions de citoyens [S.Adj.], accepteront-ils d'être tenus à l'écart?

Au temps de $X$ succèdent le temps de $Y$ puis le temps de $\mathrm{Z}$.
Will several million citizens [who are Adj.P] accept to be kept on the sidelines?

The time of $X$ is followed by the time of $\mathrm{Y}$ and then of $\mathrm{Z}$.

One practical corollary of this approach is that once the dominant forms have been blocked out, slots may be left for less important items to be filled in later on. Students are urged not to get "hung up on" individual lexical items or lower-level forms, provided the choice of such items does not effect higher-level lexical or grammatical forms within the sentence or the text.

\subsubsection{Isolating Modalizers}

The inability to rise above the level of substance prevents many students from dealing effectively with constituants that function essentially as sentence-level modalizers. A standard modalizer like tout se passe comme si, instead of being processed globally, is segmented right down to its individual word-level constituants :

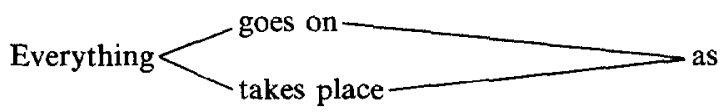

Many students need to be shown that such groups function as a block to attenuate the assertion which they accompany and must be rendered as a unit :

Tout se passe comme si notre société n'avait d'égards que pour ceux qui contribuent à la production de biens et de services

Our society seems to value only those involved in the production of goods and services

or

Our society, so it seems, values only those...

This technique makes it possible to cut through the verbosity of a sentence like :

Il faut se demander si on ne doit pas procéder à un réexamen de la place occupée par la traduction

and reduce it to two functional blocks :

$$
\begin{aligned}
& \text { assertion } \\
& \text { il faut procéder à un } \\
& \text { réexamen } \\
& =\text { peut-être }
\end{aligned}
$$

\author{
modalizer \\ il faut se demander \\ si on ne doit pas
}




\section{It then becomes possible to render as :}

It is perhaps time to reconsider the role of translation

rather than merely replicating the verbosity of the original (which I am assuming to be not only non-pertinent but also counter-productive), as in some of the excruciatingly literal word-bound renderings produced by a group of second-year Francophones (It is mandatory to think about the necessity of examining... / One must wonder if a reexamination must be done... / We must question ourselves if we should rethink...).

\subsubsection{Text Rank}

It is at the suprasentential ranks that the canonical cohesive mechanisms come into play. It is here too that even relatively advanced students working into L1 may exhibit a sentence-bound approach that renders them insensitive to the patterns structuring the text as a whole. The following are a series of exercises, some of them more suited to a parallel writing or language course, requiring increasingly active input from the student.

\subsubsection{Outlining Written Texts}

Outlining is a good technique for grasping text-level conceptual form. Emphasis can be placed on non-verbal as well as linguistic structuring devices (logical articulators, lexical fields gravitating about key words). Typographical layout for example (headings, choice of type face, indentations), if well done, constitutes a sort of metalanguage that may provide valuable clues to the conceptual hierarchies of the text. I have found it useful to demonstrate how an extremely detailed outline may be evolved simply by excerpting the various levels of typographical headings from an article published in Consumer Reports.

\subsubsection{Establishing Inventories of Open-System Cohesive Devices}

Rhetorical as well as conceptual forms may be analysed by having students work through a text to pick up, in addition to the closed-system cohesive devices (anaphora, logical connectors and the like) and positional devices like parallelism and repetition, idiolectal features such as thematic fields, lexical sets and any rhetorical devices interacting with them (cf. the coinage MacTrudeau in a text generated by the matrix sentence "The party faithful gathered to hear the Prime Minister being marketed like a Big $\mathrm{Mac} ")$.

\subsubsection{The Text as Interpretant of its Parts}

Since meaning arises at the level of form, not substance, form at any rank can be used to explicate substance. At the infrasentential level, the phrase becomes the interpretant of its constituants, as in the following example :

...past rows of squat bungalows, every garden drooping, past grenadiers of red brick, lace curtained, past ancient cement-faced cottages with sagging roofs...

Here the meaning of grenadiers can be explicated only through recourse to the abstract forms engendering the text. At the level of expression, the syntactic patterntype Adj $+\mathrm{N}+\mathrm{Adj}$, actualized by tokens such as squat + bungalows + (with) every garden drooping, establishes the triad bungalows, grenadiers, cottages, which is perceived as the actualization of the content form "house". Grenadiers is therefore a metaphor designating a type of house (one would guess that the semantic intersection would comprise 
markers such as "tall", "straight", "stiff", an assumption that is confirmed by the proximity of the antonym squat).

At the level of the entire text, the pattern of meaning (form of content) can be used to explicate individual items (substance) whose meaning is for one reason or another unclear. This approach is particularly useful in teaching technical translation to nonspecialist students, who tend to fall back on language-bound strategies as a way of coping with texts whose content they have not understood. In the following passage :

Le vilebrequin du moteur à quatre cylindres peut être équilibré sans artifice sous réserve de placer du même côté les manetons 1 et 4 ainsi que 2 et 3 (fig. VII-4). On voit, sur la figure, que les forces centrifuges $F 1$ et $F 2$ d'une part, $F 3$ et $F 4$, d'autre part, ont pour résultantes $f$ et $f^{\prime}$ qui s'annulent (sous réserve de compenser les bras de manivelle extrêmes dans le cas du vilebrequin à deux paliers).

items such as sans artifice (which most of the students in my sample glossed over with renderings such as simply) and compenser require clarification. Such clarification is provided by a series of segments which, within the pattern of meaning of the text, constitute the co-substance of the segment to be interpreted :

\section{Interpretandum}

le vilebrequin du moteur à quatre cylindres peut être équilibré sans artifice

\section{Interpretants}

- il faut ajouter des masses destinées à ramener les forces $F 1$ et $F 2$ dans le prolongement l'une de l'autre, pour assurer l'équilibrage dynamique

- le vilebrequin à trois paliers est automatiquement équilibré. (Par contre) le vilebrequin à deux paliers doit comporter deux masses pour équilibrer les bras extrêmes

- tous ces vilebrequins comportent des masses d'équilibrage

interpreted in relation to the series of items which form its co-substance, the syntagma sans artifice is seen to be synonymous with the phrase sans masse d'équilibrage. (One could also use paradigmatic co-substance as an interpretant by appealing to cognates such as arts et métiers, ouvrage d'art, feu d'artifice, artificier.)

\subsubsection{The Extented Text : Non-Verbal Texts as Interpretants of Verbal Texts}

In many cases, the entire verbal text is itself part of a larger text, that which it constitutes in interaction with the non-verbal segments (equations, diagrams and the like) that accompany it and with which it is to a very considerable extent redundant. In the passage just cited, the item compenser can be interpreted not only through the same verbal co-substance as sans artifice, but also through its interaction with a non-verbal segment, the "Fig. VII-4" referred to in the passage :

One thus uses form defined at the level of the extended text - i.e. the convergence of the diagram illustrating the text with the conceptual and lexical fields abstracted from the verbal text itself - to clarify uncertainties at the level of substance.

\subsubsection{Cohesion and Textual Emendation}

Textual emendation, while outside the translation process proper, is nevertheless a problem which the translator has to be prepared to deal with. It also affords an excel- 
Fig. VII-4

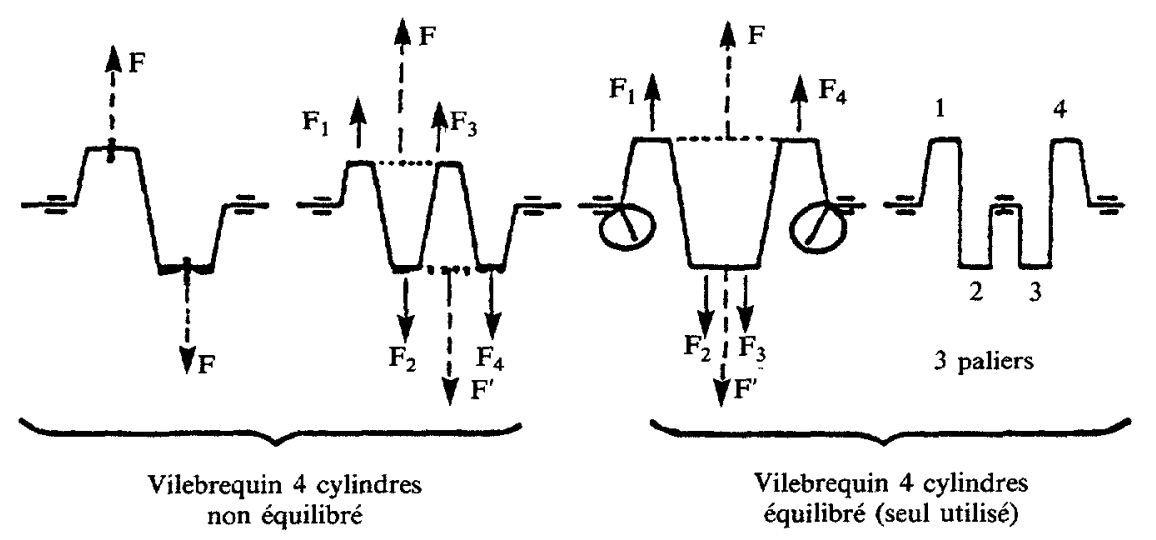

lent opportunity to help students rise above the rank-bound approach by using form to rectify poorly written or inaccurate segments (substance). In the passage cited above, the second sentence is inaccurate and must be emended to bring it into agreement with the diagram, which conveys the pattern of meaning more faithfully. The criterion once again is to give priority to form over substance : the translator should be true to the referent which has informed the pattern of meaning rather than to a fragment which falsifies this referent and deviates from the overall form.

\subsection{THE MAPPING OF FORM ONTO THE TARGET TEXT}

Once students have been sensitized to the patterns informing their source-texts, they can be taught to reactualize these forms in the target language. The translation process thus becomes a mapping onto the target text of discourse-level structures, whether cognitive, argumentative, rhetorical or semiotic, rather than of discrete items. Transfer, in a word, involves form, not substance : the unit of translation is the entire text.

\subsubsection{Blocking Out the Target Text}

One exercise that should prove invaluable in helping students to project form, not substance, involves the preparation of texts for dictaphone translation. Such preparation obviously does not involve writing out a translation in extenso, which would be selfdefeating, but consists rather in blocking out the target-text to produce a schema that will allow fluent oral translation. The schema thus produced should include the major articulators structuring the flow of argumentation, any key words or satellites whose renderings have been clarified through recourse to a dictionary or refined through the translator's own inspiration, and certain sentence-level syntactic patterns (or sequences of syntactic patterns flowing from one sentence to another), whenever such patterns are sufficiently complex or whenever a specific pattern appears particularly appropriate as a follow-up or lead-in to other sentences in the immediate environment.

\subsubsection{The Transfer of Semiotic Structures in Literary Texts}

Nowhere more than in literary translation is it true that the unit of translation is the entire text. This is something even mature translators tend to lose sight of, however, 
particularly when confronted with seemingly intractable items such as the lonicera of the following sentence from Sean O'Faolain's "Inside-outside Complex" :

...little patches of grass called front gardens, privet-hedged, lonicera-hedged, massconcrete hedged. Private. Keep Off.

The director of a commented translation can help the student retain his focus on text-level forms by insisting that he distinguish between what is functionally pertinent and what is not and by helping him to see the translation process as a mapping of textlevel equivalency classes onto text-level chains.

\subsubsection{Functional Pertinence as Integration into Form}

Independently of its rank, any given item is functionally relevant only to the extent that it can be shown to be integrated into a form. Even more crucially, the way in which it is to be translated depends on the type of form into which it is integrated. The lonicera-hedged of the example already referred to is relevant as a constituant of the playful series privet-/lonicera-/mass-concrete hedged, which in turn is relevant as a signifier of the petit-bourgeois Dublin targetted by O'Faolain's gentle satire. As substance of this particular form, it need not be rendered by a referentially exact equivalent : since the ideological load is borne by the word hedged, any plausible botanical term will do. If, however, lonicera hedge were a literary signifier of petit-bourgeois Dublin and had been integrated into the equivalency class of items constituting a Dublin-topos (as parasols, sidewalk painters, narrow cobbled streets and the bulbous forms of Sacré Coeur constitute the Montmartre of kitsch), then it would indeed have been important to find a referentially exact equivalent.

\subsubsection{Literary Translation as a Projection of Paradigmatic Onto Syntagmatic} Forms

The close critical reading that constitutes the initial phase of literary translation results in a model of the text in terms of functionally relevant features defining a certain number of lexical, thematic, stylistic and rhetorical paradigms. This analytic phase of the transfer process thus reverses the "projection of the principle of equivalence from the axis of selection into the axis of combination", a peculiarity which Jakobson claimed to be the hallmark of poetic discourse. The transfer phase proper runs parallel to the original creative act in that it seeks to re-project along the textual chain the equivalency classes uncovered by critical analysis.

After guiding the student through a longitudinal analysis focussing on the lexical, thematic, stylistic and rhetorical fields informing the text, the professor can stress the fact that what are to be mapped over are these fields themselves, not the discrete items actualizing them at any specific point :

tar sands, slush, wet earth underfoot...

sluck in, sucked down, fossilized, entrapped...

sluggish, lethal, rich and sticky, dark and shining surface, rippling...

sables bitumeux, glaise, fange, boue, bourbe, vase, sables mouvants...

engloutir, s'enliser, s'ensabler, couler, s'enfoncer, s'embourber...

visqueux, gluant, collant, poisseux, huileux, onctueux, reluisant, miroitant, moire, riche, ondulant...

This makes it possible to constitute pools of lexical items in advance for insertion into the text, not as point-by-point matchings of discrete items, but as actualizations of the underlying forms. 
Similarly, in Margaret Atwood's short story "Giving birth", the insemination of the text by the intertextual allusion to Stephen Foster's "Jeannie with the light brown hair" means that every occurrence of items such as light brown/dreaming/water, tenuous, insubstantial ("floating like a vapor on the light summer air") must be projected as part of an intertextual field running through the entire text. The nurse was light brown will have to be rendered as l'infirmière avait les cheveux châtain clair ${ }^{5}$, rather than by the referentially more plausible l'infirmière avait la peau hâlée. Similarly, the field generated by the dismantlings, permutations and recombinations of the seminal phrase giving birth must be re-projected onto the target text : For them, screaming is part of giving birth is better rendered by Pour ces gens-là, cela se fait quand on donne naissance than by the referentially synonymous and more compact cela fait partie de l'accouchement; a dislocated and unidiomatic form such as des bébés à qui naissance a été donnée must be preferred, as a rendering of the meaningfully unidiomatic babies to whom birth has occurred, to smoothings-out such as des bébés à qui l'on vient de donner naissance. Such choices, at whatever rank they occur, must reflect the priorities of form over substance.

\section{CONCLUSION}

The advantage of a definition of cohesion that is operative at every rank of the textual chain from the morpheme up, and paradigmatically as well as syntagmatically, is that it affords a unified (and unifying) approach to the practice and teaching of translation. The semiotic approach to cohesion provides a particularly simple and (in the mathematical sense) elegant guideline for the translation process : units of translation should be chosen at the level of form rather than of substance.

This guideline is pertinent for both novice and experienced translators. Focussing on infrasentential forms will improve the performance of beginners translating into $\mathbf{L} 2$; more advanced students working into L1 need to be reminded of suprasentential forms at the level of the paragraph; graduate students and professional literary translators must be sensitized to text-level forms.

It is only once the forms ensuring the cohesion of the text have been given the priority they deserve that translation can achieve the "organicity", to use Jean Delisle's term, of spontaneous discourse.

Footnotes

1. "Éléments de sémiologie", in le Degré zéro de l'écriture, Paris, Seuil, 1964 (1953), p. 111.

2. "Translation and Entropy", forthcoming.

3. I have found it useful to define meaning as the sum total of all relationships between the sign and the user, the referential framework or any other signs present in the some text or evoked. ("Les invariants de traduction et le sens de la forme", forthcoming in Strumenti Critici).

4. Most of these authentic renderings are so word-bound as to make it superfluous to provide the ST segments from which they derive, which can be retrieved through literal "back translation".

5. The problem of the TL reader's lacking the intertextual competence to respond to this component of the text is one which I have dealt with elsewhere ("Métatextualité et traduction", forthcoming in The Canadian Review of Comparative Literature). 